\title{
Women of Letters: Envois between Victoria and Toronto
}

\author{
Smaro Kamboureli and Lola Lemire Tostevin
}

\section{Femmes des lettres: lettres des femmes}

A la suite de la conférence de l'ISISSS qui eut lieu à Toronto en 1987, Smaro Kamboureli et Lola Lemire Tostevin vont échanger une correspondance dans laquelle elles se confient leurs nouvelles quotidiennes, leurs commentaires sur leurs projets d'écrits en cours, des comptes rendus sur les films qu'elles ont vus récemment mais surtout, elles discutent de manière piquantel' utilisation faite par Julia Kristeva de la 'troisième personne' qui en fait signifie le Père et sa signification pour les femmes. La fascination qu'éprouve Jacques Derrida pour les pronoms y est aussi évaluée en rapport avec la pensée de Kristeva alors que Kamboureli et Tostevin poursuivent leurs idées sur le maternel, la biographie de la Vierge Marie et le personnage du père traditionnel qui représente le désir de la mère tourné ailleurs que vers l'enfant.

\section{Dear Lola:}

Winnipeg, June 29, 1987

I'm back to my chaos, and it feels good to know that I don't have to bother with straightening it out, for tomorrow we begin the packing of our books and papers. Your bedroom, Lola, is nothing compared to my study. I love chaos; I think it's my/our signature. Wasn't everything created out of Kaos? I mean Hesiod's Kaos.

I miss our talks around your yellow kitchen table, sipping wine or scotch, Yoda brushing my foot, I even miss our uneasiness and frustration about ISISSS '87.* But things are coming together. I started

* During the 1987 International Summer Institute for Semiotic and Structural Studies (ISISSS), University of Toronto, Lola Lemire Tostevin and Smaro Kamboureli attended, among other activities, the courses offered by Teresa de Lauretis, Luce Irigaray, Jacques Derrida, and Kaja Silverman. 


\section{Tessera}

going through Kristeva's Tales of Love as soon as I got it out of my suitcase. I couldn't believe my eyes. It's uncanny. It's full of echoes of Derrida's lectures, or rather, since Tales of Love was published in French in 1983, Derrida's lectures are full of Kristevian resonances. I will not go so far as to suggest that he appropriated her theory of love; he hardly talked about love. After all ... 'it was not love, it was only infatuation ...' But, Lola, do you remember from your reading of the original that Kristeva talks of Spinoza and Scholem and ghosts, not to mention veils, etc.? She talks of the sacred and secular language, although she doesn't use the terms, vis a vis Judaism and Christianity and the Greek classic period.... I like her contextualizing psychoanalysis this way. Isn't it richer than Lacan's method of writing, or is it just my jet lag and jouissance of words? I think of the low discussion level in the Silverman seminars, some of the women's lapses into the mere empirical and experiential as if theory and psychoanalysis and language were totally devoid of the 'real.' And I' $m$ still not persuaded by Silverman's critique of Kristeva's 'third term.' I have to read Tales of Love again, and more carefully this time, but I suspect that the 'father' in Kristeva is not always the father; it is a name, yes, an overdetermined name at that, but nevertheless a name, and as such it is not a name naming the third term with threatening (to woman) precision. Here is where I wouldn't mind snuggling in with Derrida - the name of God is nothing, but nothing is always something, which, I gather, also means that something is nothing too. We have to read the 'father' as name, we have to talk about, deconstruct, naming.

Maybe it's time to unveil Derrida; maybe it's time to say, without any hesitancy, long live intertextuality; maybe it's time to let ourselves slip into the abyss and speak about love and its many veils. Speak about woman as woman, not woman as metaphor. Let woman be the metaphor of woman if we can't escape metaphoric discourse, if woman insists on speaking the language of the veil, insists on veiling language.

I'm all fired up, Lola. About my Tinos story. Kristeva again. For she speaks of John Chrysostomon's 'golden mouth' - his last name means 'golden mouth,' this John named thus because of his eloquence and his great hymns on Mary. Kristeva alludes to the hymns I intend to quote from in my story. So I got my mother's hymn book out of its 'crypt,' and I read those hymns again. They're incredible. Mary constantly 
unnamed and renamed, invariably named by metaphor and metonymy. I love and hate those hymns at the same time. For Mary is there as a 'gift,' the Derridean gift as 'sacrifice.' ...

I won't go on. I've got a million things to do. We're leaving a week from today, the farewell gatherings beginning this afternoon, I miss Yoda and your coffeepot's sighing, I don't know where to begin with my chores. I prayed to Mary for a miracle but nothing happened. Never mind. I don't take this lack of response to be a proof of her invisibility. I want to find the woman in Mary, not the goddess. The other Mary in my life, my mother, wants to visit me this fall....

Lola, thank you so so much for your hos pitality. Promise to giveme a chance to return it. In Victoria.

\section{Love, Smaro}

P.S. Columbia Univ. Press announces on the jacket of Tales of Love another Kristeva book forthcoming in translation: In the Beginning was Love. Love the new name of 'the word,' another name for God, for flesh, for pneuma. Spinoza beware of our 'vengeance.'

\section{Toronto, July 26, 1987}

\section{Dear Smaro,}

You must be settling into your new home now, still wondering where all the books are going to fit. I finally took a few days off after you left to put order to the chaos created during the conference, clothes back on their hangers and books back on their shelves. Was more tired than I realized and slept most of three days and nights, but then was so eager to get back to 'sophie that I've been working almost non-stop ever since.

Yoda 'and family' received your beautiful arrangement of flowers about an hour after I got back from the airport. They were exquisite and lasted over a week. Jan Geddes dropped in the day after you left and brought me a similar arrangement and I combined the two which made for a very spectacular bouquet on the dining room table. Very generous of you and if you consider the food money, the flowers, the wonderful meal at Corner House, etc. etc. it probably would have been cheaper for you to stay in residence.... but then it would have been my loss. Do miss our talks but feel that the entire month gave me 


\section{Tessera}

new impetus and energy and am capitalizing on that at the moment. God knows I need some source of energy since I've just learned that I didn't get the CC grant again this year. I guess I never will. Was hoping to tell Jerry that he wouldn't have to send me so much money for the next year, but.... so the story goes. How long can a person write in a vacuum with so little feedback. Half a dozen fans across the country is not my idea of great success. Sorry, I guess rejection always sets me off on this doubting course, but at least this time it hasn't left me totally incapacitated. Fuck 'em.

I had not remembered Julia Kristeva referring to Scholem in Histoires $d$ ' Amour until I reread her chapter on 'Song of Songs' and came across it. (I'm using my own version of Songs for my book-it's interesting how in this section of the bible, a woman is constituted as subject of the amorous enunciation, instead of the usual object of desire, although it can't be overlooked that it was undoubtedly written by a man.) Actually, Scholem's name keeps turning up everywhere these days, in October, in Patai's The Hebrew Goddess, and an article by Handelman, etc.... It's true there are echoes of Derrida's lectures in Kristeva, they must all be circling around the same subject in France these days since Derrida also refers to 'Song of Songs' in a piece called 'En ce moment même dans cet ouvrage me voici' (look up your Derrida package from ISISSS ' 84 ). This must be the article he referred to when I asked him about absence of God and absence of woman being the same thing. Not only does he refer to 'Songs' in this article, but he does a whole number on Emmanuel Levinas' initials (E.L.). Initials as pro-noun, (elle) and pre-noun, that which precedes naming. He draws an analogy between 'elle' and name of God which is also both Prenaming and Pro-naming. It's somewhat different from what I was proposing but he also equates 'experience' of the 'other,' whether it be God or woman, as experience of absence, so I guess it adds up to more or less the same thing. A good article, but as usual with Derrida, I'm not quite sure what I've read when I've finished reading it. And I still haven't forgiven him for how he treated women's questions during his course. I wrote a piece about it in 'sophie. Oh, and another thing he mentions in his article (actually he quotes Catherine Chalier and Lévinas) is that wanting to write differently doesn't mean a simple reversal of the language's determination but an awareness that language is not only a simple means to or condition of thought and that 'language is never neutral.' Sound familiar? The main problem with 
Irigary's course, I think was that she treated the lexicon strictly as determination, as Cartesian thought/speech/being, which would explain her comment that much of woman's writing nowadays is like a beautiful tapestry but tapestries have never changed the course of history.

I'm glad you liked Histoires d'Amour, I think it's a fine book but not without its problems. I agree with you that it's high time we stopped being threatened by the term 'Father.' Sexual discrimination was caused primarily because half the population was threatened by the term 'Mother,' and I don't think simply reversing it will achieve much. I agree with you, however, that we have to deconstruct 'the word,' and the concept behind it, which I don't think Kristeva does, although her terms are certainly more ambiguous than the way they were interpreted in Silverman's class. What Silverman failed to mention in her class was that Kristeva's book contains tales, historic tales (the play on words in the French title-histoires, both as history and fiction) of love, or the amorous space interior to the western history of 'love.' I never read the book as prescriptive but rather as summary. And I certainly can't think of any term other than that of the archaic father to describe the mother's desire which situates itself elsewhere than in the child and which is a necessary precondition for the primary separation between mother and child. Once you use the organization of mother and child and their necessary separation in the formation of another psychic space you've got to come up with a third term. If we don't like the term 'archaic father,' which is really just another term for the necessary space between mother and child, the degree zero of our archaic loves, then we will just have to come up with a new one. If we can't, then we have to deconstruct the overdetermined definition of that word. It's so fascinating how certain words take on a different significance at particular times of history and encapsulate the cultural climate of those times. And to think that some writers still don't see how autonomous language can be. How it comes to think itself in us, without our being aware of it, instead of vice versa. (And those same writers probably get all the fucking grants!)

So happy to hear that you're all fired up by yourstory about 'Mary.' I'm curious to see how you are going to handle her, not only as woman, but as mother. There's so much to be done in this area and I love the way Kristeva deals with both the poetic (personal?) side of maternal love and Christianity/Maternalism in her chapter 'Stabat Mater.' So 
far, feminism has not known how to deal with the whole issue of the maternal. It seems to me that once we refuse the image of the maternal body we create another absence. How can we keep creating significance out of 'woman' as absence? On the other hand how do we avoid the cultural constraints of that image? Anyway good luck to you and your story, I'm dying to read it.

Went to see a Brazilian film a few days ago with Penn. A film based on one of Lispector's novellas Hour of the Star. I had read it and found the film particularly well done and faithful to the book. It's about two practically vegetative protagonists, a young woman and man who exist within minimum awareness of themselves but have unrealistic dreams, or fantasies, that eventually destroy the girl. The girl is presented as being totally undesirable, although she is aware of her sexuality, and her fantasy is finally realized, but at the ultimate cost. It's quite brilliant, another version of the impossible couple, a different mythical Romeo and Juliet whose fantasies around love are just another side of death. God I love that writer. Have also been reading Duras' La vie materielle. I was surprised to learn that Yann is gay, especially after reading his M.D. Well he may have bisexual episodes, but that's not made as clear as the fact that he's 'homosexual' to quote Duras. It sheds a different light on their relationship, although I'm not sure why. They seem to be totally happy together and she claims that neither one of them wants to live if the other one dies. It will be interesting what happens when that comes to pass....

I wrote a wacky offensive piece inspired by the 'Semiotic of Eroticism' weekend. Thumper and all. When I think what could have been done with that colloquium and what actually transpired.... We had the opportunity to raise so many important questions ... but zilch. Will send you the piece along with several new ones in a few weeks or so.

I've decided not to rush the finishing of 'sophie too much since I really want to be happy with it. I also want to get down to my novel, which means there won't be any poetry writing for a while so might as well give 'sophie all I can. I should have most of it finished by the fall however, and will send a copy of the ms then.

Well Smaro, I did go on much longer than I intended. Everything is basically going well in spite of the CC rejections.... Jerry was just here for a few days and we had a very nice time. I think we are both mellowing. It's been excruciatingly hot in Toronto - we've broken all records 
and I hate to think of the cool Pacific breezes you must be enjoying in your new hometown. What did you do with your first paycheck?

Love and kisses to both you and Robert and do write when you have a chance. I just asked my computer to verify the spelling of this letter and it asked me if the word 'Smaro' was meant to be 'smart'? and if 'Derrida' was meant to be 'deride.' I love it.

Love,

Lola.

\section{Victoria, October 6, 1987}

\section{Dear Lola:}

I loved your letter-the manyletters of your words-and, please, do give my best to your computer spelling program - from 'smart(y).'

Where to begin? Victoria is lovely, utterly beautiful and seductive. Well, when I say Victoria I refer to the general area, although I do like the town as well. But the downtown area is too pretty, too conscious of its design. Living close to the ocean is very important to me. By sheer accident, I live again, again after eleven years, a ten-minute distance from the littoral line - littoral line/literal life. Thessaloniki is with me again, in spirit and in smell. This is what I like best about the sea, its pungent smell, the salt invisible in the air, breathing iodine. Amniotic (es)sense.

We love our house. It's the right place for us - right size, privacy, lots of trees - I counted thirteen oaks. I have no sense of the department yet, but I'm determined to like it. Did I tell you this before? Determination occurs too frequently in my vocabulary these days, what with a geographical move and the beginning of a career. This last word scares me a bit, locating one's self in the tightness of institutions.

Stephen gave me a gift which he got in Paris: Derrida's feu la cendre. No time to read it now, but just by paging through it I got the sense that it's about 'elle,' elle of 'la cendre,' etc. Probably I will not get into it for awhile; let me know if you want me to send it to you.

Yes, I took another look at my Derrida papers from ' 84 . That fascination with pronouns is interesting. Investing the trace of phone (elle/ il) with signification (not meaning). But doesn't this signification, the 'experience' of the 'other' as 'absence,' become absence precisely because we locate it in the space of the gap? If the gap is the sign of the differentiation processes in language, doesn't it also reside outside of 
language - gap as absence, that is - ? It seems to me that we need to explore more that kind of contextualization, retrieve the figure of the gap from absence. For if we can define, ever so tentatively, the gap, then it ceases to be absence, or, rather, absence ceases to be informed by nothingness. I'm not trying to come up with any positivistic or essentialist definitions. Like you, I fear that reversals are not adequate strategies; they simply perpetuate the old dialectics. But I want to know more about the intertextuality of language and 'experience.' Yes, language is not neutral. I often feel that it is a living organism that threatens to consume me, that envelops me with ambiguous intentions.

Writing in Mary's voice reinforces this feeling: on the one hand, I feel that I'm engaged in a purely imaginative act - well, not quite so pure-ly, given the historical context and the church's 'Fathers'; on the other, I want to let her talk as a woman. I somehow think that her voice as woman is inscribed out there, must be written somewhere, voice/ writing as trace. Am I wrong to assume that these traces inhabit all of us? that she can speak best through anachronism, anachronism both with reference to the past and the present? I don't know yet if she knows what she knows because she's goddess - not the same as being the mother of God - or because I make her speak this way. Kind of a naïve problem, $n^{\prime}$ est-ce pas? But I still think that I ought to explore more, still in the same directions we have been discussing.

And so I wonder about what you said: 'once we refuse the image of the maternal body we create another absence.' I agree with this, but at the same time I resist the necessity, almost determination/determinism, of defining woman solely through the maternal. Maybe this is my own experiental fallacy, not being a mother, never having got pregnant. Maybe.... The fact, as Kristeva herself points out, that we have to invent a biography of Mary suggests to me that she lacks a bios, a life, exactly because she was a mother.Suspending for a moment the literal aspects of the mother/child relationship, I wonder whether or not 'motherhood' was invented as a state of being for woman, a symbolic state not a semiotic one, so that woman could be denied her otherness, her other roles. By invention here I mean the venting of woman, venting as the opening or slit of her body, the necessary wound, the prenoun, pro-noun of a child; venting as the discharging (birthing) process that also discharges woman from her womanhood; venting as the selling out of motherhood/womanhood. 
And the rituals of these processes. The appropriation of motherhood as a role that empowers, while restricting, women.

I agree re the third term, but - back to ouryellow table talks -I don't understand why it ought to be the Father. It's the power of naming that scares me here. Yes, it's an archaic father; yes, we' re talking about a psychic space; but isn't this father also the father of the child, the father of the mother? don't we 'paternalize' woman? I'm not sure I understand what you mean by the 'archaic father.' Well, yes, I see the figure there, a figure that partly accounts for the very relationship between mother and child. But I don't think this is what you and Kristeva mean by the 'third term.' In the section 'Orality Dedicated to the Father,' Kristeva says that 'Christianity, by ... inserting a Third Party between the Self and its destructive hunger, by setting up a distance between that same self and its nurse, offers to destructive avidity-a Word' (p. 149). I 'want' to read this as the third term being language. When Lacan talks about the child's mirror stage, its jubilant activity in front of the mirror, $I$ hear the child's jubilant noises as sounds, as words separating it not only from its mirror image but also from the mother. This is the case for the child. I'm not sure what happens for the mother. Since she has already gone through that stage herself, maybe it's the child's own entry into language that effects the separation, plus the mother's own ability at this stage to enunciate her otherness by seeing her child's otherness. Am I making any sense? I 'see' the mother seeing herself and the child in the mirror in front of which the child stands.

I started writing my essay on your work. I liked Janice's essay a lot. What I'm trying to do, at least at this point, is to discuss motherhood in your work through the theoretical discourse that you use. In other words, I see theory as the 'third term,' theory positing anotherversion of experience through the foregrounding of language.

Lola, I'm continuing after your call, that is to say a few weeks after I wrote the above.

I saw a wonderful film the other night, A Dream of Passion. It's a Greek film, partly in Greek and partly in English; a contemporary rendering of Medea's story. Medea's killing of her children (all sons in the myth) is not a crime directed against them - they are innocent, as the film goes, so they are readily accepted by God in the film's scenario; what she kills is their father's, her adulterous husband's, seed. I don' $t$ have the time to go into great details about the film, but Medea offers 


\section{2 - Tessera}

another version of Motherhood. Medea the witch, Medea the princess. She kills children and her husband's mistress but not the husband/father himself. She kills his seed instead. I think that 'my' Mary knows about Medea, for she wonders at one point how she can mother (love) the son of God, father of us all? She is pissed off at God, and falls in love with Gabriel. So there. God as a cuckold.

Robert sends his love. I envy you your exotic trip. Enjoy yourselves.

Love,

Smaro

p.s. still a bit more after your call last night (Nov. 15). As I said on the phone, I love'sophie. More about it later, for I have to prepare one class and write three entries today. 'sophie will change the direction of my paper on you. Oh, I'm excited so. You're so fucking good. Let the bastards give grants to those who affirm what has been affirmed already.

Toronto, December, 1987

Dear Smaro,

Wish you and Robert lived a little closer. It's cold in Toronto, especially after Australia and New Zealand with their creamy orchids and multicoloured parrots flitting about wondrous mountains and I find myself thinking more and more about living in warmer climes, maybe on the West Coast. Plus I'm feeling isolated here with no one with whom to exchange, etc.... While I enjoy these letters, it's not as much fun as our yellow table talks, 'liquidating' a bottle of scotch. I'm managing to keep busy though. Finally got a course at York, teaching creative writing and enjoying it, although I wouldn't want to do it forever. Can you ultimately teach anyone how to write? Or even instill a minimum amount of motivation?

As usual I enjoyed your last letter enormously. Reading you is always so thought provoking, so perhaps if I were to move to the West Coast, I would lose this great opportunity. Although I think I may start complaining at the length of time between your missives.... You won't be able to use the excuse that you are settling into a new home and job forever you know.

Some of the points you bring up in your letter would make for very animated discussions indeed. I must disagree with you when you write that motherhood was 'invented' (I've always disagreed with de Beauvoir on that) but rather the narrow definition by which we have 
traditionally known it was invented, undoubtedly, as you point out, to keep women in their 'place.' Of course I'm against defining Woman solely through the maternal (I'm against defining Woman, period; as Kristeva points out, 'la femme ce n' est jamais ça'), but does that mean we should disavow the maternal totally? We are all affected by the maternal whether we choose to have children or not. We've all had mothers and all girls grow up with the potential of becoming mothers. Surely, having had that potential translates differently from never having had it. As Kristeva asks at the beginning of 'Stabat Mater,' does the choice lie only between the traditional representation of the maternal or its total negation? For me this is no longer an issue, conceptually or experientially, and I am convinced that to deny the maternal will create yet another absence which women can ill afford. It has nothing to do with whether some women bear children while others don't. As de Lauretis emphasized last summer, we must focus positively on the many differences between all human beings, but perhaps more importantly for us, between women. We must focus on an ideology of difference, not as binary opposition, but as multiplicity of differences which defy definition. I know what motherhood has done for me, in a very positive sense, so I get impatient when anyone tells me that mothers' other selves can't be fulfilled. We have to get rid of that notion, that image. In my case, my other selves were enhanced through the maternal, you could say it provided me with additional intertextuality. What you refer to as 'birthing' or 'venting,' and which you define as the discharging process through which woman is discharged from her womanhood, I refer to in Gyno-text as 'vagin/vagir,' a sensuous, positive experience which doesn't 'discharge' woman from her other selves but allows her to regain control of her body and language. To paraphrase Shirley [Neuman] in A Mazing Space, the symbiosis of the maternal and foetal bodies allows the maternal to write in a different rhythm, in order to recover control of both her maternal and sexual discourses. I agree with you however that motherhood cannot be the locus of her difference, otherwise she will be absorbed by it.

Nor do I believe that Kristeva suggests that a biography had to be invented for Mary simply because she is a mother, since she makes it clear that Mary is also the daughter and the wife of her son/god. It seems to me that she is suggesting that a biography had to be invented because Mary's sexuality had to be denied. Not only did she have to be a virgin but like Jesus she also had to be 'immaculately' conceived to 


\section{$24 \cdot$ Tessera}

assure her eternal life. Since sin (sexuality) and death are inseparable, neither Mary nor Jesus could be conceived in 'sin,' so a mother and a father (Ann \& Joachim) who hadn't 'gotten it on' in years had to be invented. What bothers me about Mary is not that she is a mother, because she embodies much more (mother, goddess, queen, daughter, wife), but rather her inaccessibility other than in relation to the ultimate authority figure. That is the aspect of the maternal that bothers me. Not motherhood per se. In an interview Kristeva emphasized that maternal love was one of the book's (Histoires $d^{\prime}$ Amour) personal points of departure and that the chapter 'Stabat Mater,' dated 1976, related to her own experience of maternity which allowed her to write in a more 'poetic,' more oneiric manner.

By the way, I'm delighted you've made Mary unfaithful to God in your project, unfaithful with God's very own messenger no less... you can never trust those underling messenger boys when it comes to the boss's wife ... I guess when the Bible says that Gabriel 'came in unto her' he really came in unto her, and all the time the old guy upstairs thought he was working miracles! So typical of Patriarchy, isn't it? Would rather invent superhuman cock and bull stories about holy ghosts and virgin births than admit It's a cuckold. Sounds great and I can't wait to read some 'samples.'

Coming back to the 'third term' (I don't want to beat this to death), as I pointed out in my previous letter, I' $m$ not totally comfortable having it defined as 'Father' but then neither can I see why, given the Mother/Child combination, we can't have the third element as Father. I don't believe this paternalizes 'woman' per se, but the child, and there shouldn't be anything wrong with that as long as we continue to 'maternalize' the child as well. We wouldn't be so threatened by this third term if the boundaries weren't so sharply delineated and divisive and if we didn't accord so much authority to the term of the Father. I have no doubt that Kristeva sees the Word, linear language, theory, as belonging to the third term (Symbolic), but I think perhaps the reason she doesn't mind assigning the third term to the Father is that she doesn't give it any more authority than that of the Mother (Semiotic). While she has always emphasized the importance of exceeding the Mother/Child relationship, she has also emphasized the importance of not suppressing it. The child cannot remain in the emotional or physical envelope of the mother, which exists in too great a proximity, so an 'imaginary father' is introduced as a loving 
third with which the infant-in-processidentifies but not at the expense of the semiotic or the mother. This permits the investing of drives in the symbolic, and consequently the creating of a space of play and exchange between the semiotic and the symbolic. I would like to think that these letters (or our writing in general) do not belong to the third term, as you say, but to the space between terms.

You mention Lacan and the mirror stage and ask what happens to the mother when the child discovers her 'self' and her babbles and separates from the mother. Well maybe the mother has something else to love beside the child. Maybe she has her own work, as well as husband, lovers, friends. Maybe she's very creative over and above child bearing. The difference between Kristeva and Lacan is that Kristeva puts more value on what happens before the mirror stage, before the Symbolic, which seems to prepare the mother far better for the space of exchange, interplay, etc....

Which brings me to the question of the gap. I'm not sure what you're saying here. Are you suggesting that through language, through definition, however tentative, we can retrieve a figure from absence? Isn't this precisely the metaphysical enclosure which Derrida says gives the illusion of retrieving origin, comforts human beings with the notion of presence, when in fact the only presence we're left with is the language with which we attempt to define? Doesn't the experience of the 'other' remain as absence? Well, my dear Smaro, you are certainly felt as absence these days, so please don't wait too long to fill that gap with the presence of a big fat letter.... (If anyone were to read this I'm sure they would hang many of their sexual symbols onto this last image....)

According to Coach House 'sophie has been 'keyed in' and should be out in February. Since it's due very shortly, I won't bother sending you the changes I was telling you about on the phone. If you do write an essay, it will be easier to have the page numbers, etc.... Shouldn't be much longer. I'm nervous about this one, especially now that it's out of my hands. I know that my effort to penetrate the psyche around the amorous discourse is going to be interpreted as nostalgia instead of the process of a woman constituting herself as the subject (vs object) and enunciator (vs spoken for) of the amorous discourse. I'm sorry you were bothered by the piece on the semiotic weekend conference but I meant it to be as distasteful as possible. To me most of that weekend was offensive and a perfect example of how many academics are 


$$
\text { 26. Tessera }
$$

not able to extricate themselves from the traditional and sexist definition of eroticism.

Will probably speak to you shortly. Loved my postcard from Robert, it made me want to pack up and move immediately. Maybe a visit before you go to Greece? I could use some warmer weather. Anyway, love ya Smaroula and write soon!

Big hugs to both,

Love,

Lola

This time my computer asked me if Beauvoir was meant to be beaver and Lauretis was meant to be laureate. I think it can read my mind. 